\title{
The Maternal Performance of the Virgin Mary in the Old English Advent
}

\author{
MARY DOCKRAY-MILLER
}

Throughout the Christian era, literary and artistic representations of the Virgin Mary have been manipulated by a variety of ideologies, religious or political, to define the appropriate positioning and agency of the feminine in a culture. The culture of Anglo-Saxon England, like most others, almost always presented Mary in positive terms, celebrating her for humility, purity, and passivity. In the Advent Lyrics of the Exeter Book, however, Mary's ideal and idealized femininity does occasionally reveal its precarious underpinnings in metaphor and in its need to disempower the Mother. Analysis of the metaphors and diction that refer to Mary, especially in lyric nine, reveals her as a necessarily female, maternally embodied, active subject in spite of the text's traditional figurative language. This reading as well permits twenty-first-century scholars to expand our understanding of the possible audiences of the poem to include professed religious women associated with Exeter Cathedral.

Keywords: Advent Lyrics / Anglo-Saxon poetry / Anglo-Saxon religious history / Christ I / Exeter Book / Marian devotion / Virgin Mary / Women's Christian spirituality

The figure of the Virgin Mary has meant many things in many cultures. Literary and artistic representations of the most important female in Christian narrative have been manipulated by a myriad of ideologies, religious or political, to define the appropriate positioning and agency of the feminine in culture and society. Inquiry into the dynamics of Marian devotion is as strong at the beginning of the twenty-first century as at any time in the Christian era; many recent spirituality movements, whether New Age or more traditionally faithful, have tended to focus on women and female connections to religious practice. Investigation into the history of Marian devotion can inform our understanding of women's spiritual and religious practice in our own time; such investigation can provide a connection with the history of women and with the history of women's spirituality, thus deepening our understanding of the roots of female-centered spirituality, especially Christian spirituality, in contemporary culture.

While Anglo-Saxon England can seem vastly foreign and distant, its culture provides an early example of a type of female spirituality and Marian devotion focused (somewhat precariously) on the female body and the maternity of the Virgin Mary. The culture of England before the Norman Conquest (1066), like most others, almost always presented or 
discussed Mary in positive terms, celebrating her for her humility and purity. These representations, however, celebrate her as a passive and objectified-albeit positive-maternal figure. Indeed, such passivity and objectification are integral parts of the overwhelming virtue of the Virgin Mary. At least one Anglo-Saxon text, however, reveals slippage from this norm of passivity and humility.

In the Advent Lyrics of the Exeter Book, Mary's ideal and idealized femininity does occasionally reveal its precarious underpinnings in metaphor and in its need to disempower the Mother. As such, Mary of Advent and her son form a mother-child pair that both demonstrates and unsettles an oppositional masculine/feminine paradigm. Detailed analysis of the metaphors and diction that refer to Mary throughout the lyrics reveals her as a necessary female and maternal body that asserts itself against the traditional figurative language of the text. Such a reading-most evident in the nativity tableau of lyric nine-allows a shift in the critical view of Mary as passive and humble to one wherein she can be read as embodied and active. This reading also permits twenty-firstcentury scholars to expand our understanding of the possible audiences of the poem as its manuscript enters its second millennium.

The narrative action of Advent, as I will refer to the poem, ${ }_{1}^{1}$ is one of praise of Christ that focuses on his birth and its relation to Christ's mercy for humanity. Each of its twelve sections begins with Eala, the Old English equivalent of the " $\mathrm{O}$ " that begins each of the antiphons sung during the Advent season. ${ }^{2}$ A brief summation of the contents of the twelve lyrics reveals a movement through Mary's pregnancy to the birth of Christ, although the praiseworthiness of Christ is the main subject of each:

1. 11.1-17: a plea for Christ to restore the crumbling temple of humanity

2. 11.18-49: a plea for Christ to release us from the prison of life

3. 11.50-70: praise of Jerusalem as the city of Christ

4. 11.71-103: a dialogue between the Virgin and a son of Jerusalem about the mystery of her pregnancy

5. 11.104-29: praise of Christ as the morning star

6. 11.130-63: praise of Christ as King of Heaven

7. 11.164-213: a dialogue between Joseph and Mary about the legitimacy of her pregnancy

8. 11.214-74: a plea for Christ's mercy

9. 11.275-347: praise of Mary as Virgin Mother of Christ

10. 11.348-77: a plea for Christ's love and mercy

11. 11.378-415: praise for the Trinity

12. 11.416-39: praise of the virgin birth of Christ

Although my argument ranges throughout the lyrics, I will be focusing most specifically on the seventh and ninth of these divisions, as those are the sections that treat Mary most thoroughly. As I analyze Mary's 
gender performance in these lyrics, I hope to show how her oppositional or traditional femininity, defined against Christ's (and others') masculinity, is challenged by her maternal performance. That performance allows a wider, more inclusive understanding of the Exeter Book's eleventh-century audience and a deeper twenty-first century understanding of early Christian women's history.

Advent is the first poem in the Exeter Book (Exeter, Cathedral Library, MS 3501), a book possibly made at and still housed in Exeter Cathedral. ${ }^{3}$ When Bishop Leofric moved the episcopal see from Crediton to Exeter in 1050, he listed the books he donated to the library, including a mycel englisc boc that is most likely the Exeter Book (Krapp and Dobbie 1936, ix). The Exeter Book is unusual because of its mix of secular and religious poetry; in addition to Advent and numerous other religious poems, the book contains riddles, gnomic wisdom, and a number of secular poems, including the enigmatic "The Wife's Lament" and "Wulf and Eadwacer," both of which have female narrators. Most scholars place the manuscript's production and content within the context of the Benedictine reform, a religious movement that spanned the tenth and eleventh centuries, invigorating Anglo-Saxon culture with rigorous monastic and intellectual practice. The manuscript's contemporary use and reception were probably monastic; it could have been used for private or public reading in the monastery. Scholars tend to assume that such uses and receptions were male, ${ }^{4}$ but I hope to show later in this essay that women could have used the Exeter Book, and Advent as well, its first text, in their devotional reading.

Editors and critics have tended to view the Virgin Mary of Advent in traditional doctrinal terms, as the mother of God whose importance stems wholly from her relationship, both literal and metaphorical, with Christ. Mary Clayton's extensive treatment of the poem in The Cult of the Virgin Mary in Anglo-Saxon England acknowledges its "striking emphasis upon the virgin" even as "Mary's importance, in the poet's view, is clearly the result of her role as Dei genetrix, and she is viewed largely in Christological terms" $(1990,202)$. Clayton's reading of the figure of Mary in the poem supports her argument for an earlier rather than later date for the poem's composition; by the very end of the AngloSaxon period, according to Clayton, the cult of Mary was strong enough to focus on her alone rather than on her relationship with her son (205-6).

Critical views of Mary's traditional femininity in Advent-a passivity shaped by its relation to men-tend to read Mary as an archetype idealized but never realized elsewhere in Old English literature. This critical tradition has consistently viewed Mary as a figure that must be interpreted metaphorically and thus and disembodied. Such tradition has done so unconsciously, removing the material body from the text by interpret- 
ing it as a metaphor and discussing the Virgin, whose very epithet refers to her body, in terms that subordinate her to masculine desire and that relegate her existence to her relationships with masculine figures. For example, Jane Chance's reading of the poem argues that the Virgin Mary of Advent presents an ideal Anglo-Saxon femininity that "fulfills all of the roles normally available to women: young girl, virgin, bride, and mother" (1986, 187-8). Chance also sees Mary as peaceweaver in her role as intercessor between God and humanity, fulfilling another traditional role for Anglo-Saxon women. For Chance, Mary's ideal femininity stems from her absolute success in a variety of roles, all of which entail that she subordinate herself to the desires of a masculine figure: the angel of annunciation, her son, her earthly husband, or a petitioning humanity. ${ }^{5}$

In such interpretations of the poem, Mary's body exists solely as the vehicle for Christ's entry into the world. That female body, however, then disappears in insistent metaphorical presentations in, and interpretations of, the poem. Edward Irving, for example, elides Mary's body completely in his analysis of the poem when he refers to "the cosmic creative act, wherein the Father generated the Son" $(1996,126)$. In this poem, then, the central Christian narrative depends on both a female body and the rhetorical disappearance of that body; this disappearance emerges in the text as metaphor, although such allegorical interpretation of Mary depends, ironically, on her body and on her relationship to Christ as human mother.

Robert Burlin discusses the metaphorically disembodied and figure of Mary to an even greater extent than most other critics; the subtitle of his edition is "A Typological Commentary" (1968). He notes that patristic and theological types and symbols of Mary are often things rather than people: the Tree of Jesse, the enclosed garden. In contrast, prefigurations and types of Christ are much more frequently people than things: Isaac, Adam, Joshua (19). Mary's metaphorical equivalents are objects without bodies, just as Mary, in much of the poem, is constructed as an object without a body. The two main metaphorical objects that replace her are the temple and the gate; at the same time, the poem repeatedly refers to the Christian traditions that have allegorized her as Queen of Heaven, Mother Church, and Bride of Christ.

Much of Burlin's typological discussion of the Virgin focuses on the metaphor of the locked gates for Mary's virginity in the ninth lyric (11.301-25), in which the necessity of Mary's textual positioning as an inanimate object acted upon by God and Christ becomes clear. ${ }^{6}$ In the ninth lyric, figures for Mary include $x$ pelic ingong (the noble gate [1.308a]), gebunden / deoran since duru ormæte (the huge door bound with precious treasure [11.308b-9b]), ðas gyldnan gatu (this golden gate [1.318a]), and pæet wealldor (that wall-door [328a]). Only God can pass through these locked gates, and their integrity is not tarnished by his 
passing; they are a figure for Mary's eternal virginity prepartum, in partu, and postpartum.

Within its eternal virginity, Mary's maternal body provides the evidence for Christ's dual nature as human and divine. That body is allegorized and described in metaphor, but its necessity as body to the narrative cannot be denied. Mary's body is both fetishized and neutralized, performing a traditional, oppositional femininity as she acquiesces to this male-dominated narrative. She is the object of the angel's orders, wherein the angel tells her

$$
\begin{aligned}
& \text { pæt pu sunu dryhtnes } \\
& \text { purh clæne gebyrd cennan sceolde } \\
& \text { monnum to miltse, ond pe, Maria forð } \\
& \text { efne unwemme a gehealdan } \\
& \text { (297b-300b) }
\end{aligned}
$$

[that you the son of the Lord through clean birth must bear as a grace for men, and that you must, Mary, thenceforth keep yourself ever from uncleanliness].

After Mary receives the annunciation, the lyric turns to the annunciation's fulfillment of the prophecy of Isaiah (11.301-25), in which the gates are described as a prefiguration of Mary's virginity (see n.6 for full text and translation). These lines describe a specifically masculine (Isaiah is called woðbora, wise man [1.302]) vision of female bodily sexuality, in which ensuring female bodily purity is as simple and controllable as locking the gates. God the Father controls access to them and none but he will pass through:

$$
\begin{aligned}
& \text { ðas gyldnan gatu giet sume sipe } \\
& \text { god sylf wile gæstes mægne } \\
& \text { gefælsian, fæder ælmihtig, } \\
& \text { ond purh pa fæstan locu foldan neosan, } \\
& \text { ond hio ponne æfter him ece stondað } \\
& \text { simle singales swa beclysed } \\
& \text { pæt nænig oper, nymðe nergend god, } \\
& \text { hy æfre ma eft onluceð. }
\end{aligned}
$$

[the golden gate yet in some time God himself in the spirit's power will pass through, the Father Almighty, and through the bound locks visit the earth, and they then after him eternally stand, always forever so fastened so that none other but the savior God may ever again unlock them.]

The gates are thus passed through, locked, and unlocked with a series of passive verbs; they never open or close of their own volition. Clayton remarks that "the closed gates as a figure for Mary's conception [of Christ] are, of course, a commonplace" $(1990,199)$, but it is exactly the familiarity of the metaphor that lessens the gendered impact of the gates 
as passive-even inanimate-objects that stand for the female body. ${ }^{7}$ Christ locks Mary's body after his passing through with a liopucægen (body-key [1.334a]) in a figure vaguely reminiscent of one the "obscene" riddles later in the manuscript-Riddle 42 , which is ostensibly answered with the word key but actually with the word penis. ${ }^{8}$

Even Mary's existence is spoken by others; in the beginning of the sequence, she is named and spoken by speech-bearers as a direct object (pec mid ryhte ealle reordberen / hatað ond secgad, with righteousness all the speech-bearers name you and bespeak you [11.278a-9a]). Many sentences that contain you (Mary) as a subject have a form of the verb to be as a main verb (bu sie, you may be [1.284a]), implying stasis rather than action. The only part of the ninth division in which Mary is grammatically an active subject occurs at lines 287-90a:

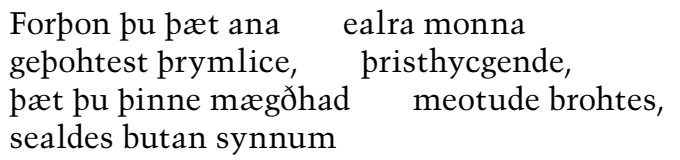

$$
\text { (11.287-90a) }
$$

[Therefore you alone of all humanity splendidly strong in mind determined that you would bring your maidenhood to God, would give your maidenhood without sin]

These lines may be a reference to Mary's apocryphal childhood vow of herself and her virginity to the temple in Jerusalem. ${ }^{9}$ In these lines, Mary is acting to serve God in accordance with God's will. It could be argued that Mary is here actively submitting to God's will (thus assigning some sort of agency to her). The vocabulary of these lines is reminiscent of heroic diction-prymlice (glorious), pristhycgende (brave-minded)imparting a degree of courage and valor to Mary's submission. It is, nevertheless, the submission of a feminine figure to a masculine deity, and as such it reinscribes a traditional, stereotypical masculine/feminine opposition. Edward Irving uses such an oppositional structure in his analysis of the esthetics of Advent (which he calls Christ I), wherein he delineates a succession of relationships such as light/dark, father/mother, and ultimately heaven/earth, equating the feminine, human, maternal with earthy darkness (1996, 131-2).

Such grammatical structure of active and passive construction sets up a binary within language from which it is difficult to escape. Grammatically, Mary is almost always an object or passive subject. In the remainder of most of the diction of section nine, the grammatical structure emphasizes her passivity and objectification, actions performed upon her by others. She is on the receiving end of orders and imperatives: $p æ t$ pu sunu dryhtnes / purh clæne gebyrd cennan sceolde (that you the son of the Lord through clean birth must bear [11.297b-8b]), Iowa us (show 
us [1.335a]) and Gepinga us (intercede for us [1.342a]). These verbs are imperatives, not hortatory subjunctives; they order rather than plead. She is celebrated throughout as an allegorized and serving feminine figure, controlled by the will of a masculine, patriarchal God.

In this sequence, Mary's is not a material maternal body, though all of Christological doctrine depends upon that body. Clare Lees, in her discussion of the place of sexuality in Anglo-Saxon literature, also argues that the doctrine of the poem necessitates the metaphorical reading of Mary's body. She states that:

$[T]$ he female body, which shadows the entire lyric, is the ground of this image, offering the conditions whereby it becomes comprehensible. What we see, in short, is and is not a female body. $(1997,30)$

In the metaphors of lyric nine, Mary's body is reduced to what could be perceived as a grotesque allegory of a giant, locked vagina: the gate through which only God can pass (God the father as she conceives, God the son as she gives birth). The image of the gate centers attention on Mary's bodily intactness; the explicit physical nature of that intactness, and its focus on the physiology of female genitalia, no matter how couched in metaphor, must be acknowledged. Lees refers to "the image of the Temple/door/vagina/womb" (30). In this sequence, the metaphor of the gate glosses over the physical nature of Mary's crucially important virginity to the extent that it becomes a thing she can bring to God, like a present in a box, rather than a material bodily attribute. In Advent, through objectification and allegorization, Mary's maternal body disappears in a typological reading and indeed in the very structure of the poetic language itself.

That body resists metaphoric interpretation and provides Mary both agency and the power of speech in lyric seven, however, revealing the precariousness of a narrative that relies upon the metaphorically silenced and maternal body as its cornerstone. The seventh lyric, traditionally termed "the passus," is composed almost entirely of dialogue between Mary (who is pregnant) and Joseph. ${ }^{10}$ There are a number of grammatical structures in this seventh section, similar to those of section nine, that make Mary an object even within her own active speech. By Mary's own admission, she is passively made a temple ( $\mathrm{Nu}$ ic his tempel eam / gefremed, now I his temple am made [11.206b-207a]), and she must bear life's glory (sceolde ic lifes prym / geberan, must I life's glory bear [11.204b-205a]), with no choice in the matter. Even as she speaks these lines, she makes apparent her own grammatical position as passive subject. $^{11}$

At the end of this section, however, Mary does begin to show some agency that figures a form of maternal disruption. Relying on her bodily relationship to Christ to provide authority, she disrupts the paradigm 
of traditional feminine passivity at the end of her final speech as she instructs and even commands Joseph. The boundaries of that final speech are not in any doubt (as the rest of the speech boundaries in the lyric are); the structure of the poem makes clear that it is Mary speaking: $p a$ seo frmne onwrah / ryhtgeryno, ond pus reordade (then the virgin revealed the right-mystery, and thus spoke [11.195b-196]).

This final speech begins with much the same sort of grammar and content that present Mary as a feminine object worked by a masculine will in lyric nine. She relies on the authority of Gabriel when she says:

$$
\begin{gathered}
\text { ac me eaden wearð } \\
\begin{array}{c}
\text { geongre in geardum, } \\
\text { heofones heagengel, } \\
\text { hælo gebodade } \\
(11.200 \mathrm{~b}-202)
\end{array}
\end{gathered}
$$

[But to me became granted when I was younger in years, that which to me Gabriel, heaven's high angel, with holiness announced]

By the end of this lyric, however, Mary is commanding Joseph to give thanks for her pregnancy and his (earthly) fatherhood, using an imperative (saga) like those the petitioners direct to her at the end of section nine. To assume such a position of authority, she relies on her body and her maternity:

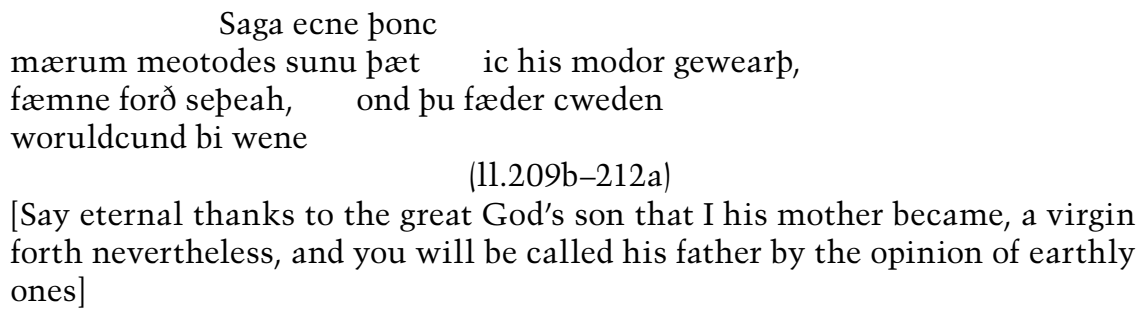

[Say eternal thanks to the great God's son that I his mother became, a virgin forth nevertheless, and you will be called his father by the opinion of earthly ones]

While the lines that evoke a traditional passivity for Mary refer to her maternity only metaphorically, that same maternity, when explicit, conversely provides Mary with authority in the seventh section. This authority exists in a state of tension with the passive construction of the Virgin, the process of objectification that started when Christ chose Mary as his mother at 1.36, mægð manes leas, pe he him to meder gecease (the maiden free of man, whom he chose for himself as mother), reversing the usual biological process of the adult deciding to have the child.

This analysis of sections nine and seven has shown that within the poem and within related critical literature about Advent, Mary is defined almost solely by her relationship to Christ, a relationship that depends entirely upon Mary's female, maternal body-the body that almost disappears in metaphor and grammar. I wish to focus now on that material body and resist the allegorization that has been textually performed upon 
it. At the end of lyric nine, after the extended metaphor of the gate, the physiology of the maternal body asserts itself. The nativity tableau-the description of the mother and child that ends lyric nine-reveals the physical underpinnings of the Christian narrative of Advent; in the midst of majesty and mystery and metaphor, the baby must nurse at his mother's breast. At the nativity, the lyrics cannot help but remind us of the physiological needs of the infant and the unique physiological abilities of the mother's body to meet those needs.

The very structure of the language shows the necessity of the body to Advent and the advent: nu we on pret bearn foran breostum stariad (now we look on that child at the breast, [1.340]). Clayton has remarked on the originality of the nativity tableau, which is "a departure from the antiphonal sources" and "a remarkable image of the congregation beholding the child at Mary's breast." Clayton notes as well that no visual art depicting Mary suckling Christ survives from Anglo-Saxon England, emphasizing the unusualness of this image within Anglo-Saxon culture (1990, 200-1). In a poem so strongly grounded in metaphor, the inclusion of the nativity scene seems doubly unusual-in its originality and in its contradiction of the poem's more typical presentation of Mary's body in metaphor.

The text of the poem bids us to look on the mother's lactating body. Lees discusses the erotics of this gaze, as the poet bids us to enjoy scopophilically the partial nakedness of Mary's body in this tableau (1997, 31). Jackson Campbell expresses some critical discomfort with Mary's female body, most overtly in relation to these lines, which he terms "the only spot in these twelve Christmas poems where the intimate and slightly sentimental image of the mother and child is insisted upon" $(1959,27)$. The literal physiology of motherhood, the baby nursing at his mother's breast, is negative in Campbell's terms; it is intimate and insistent. Burlin avoids Mary's lactating body altogether, subsuming the tableau into his typological analysis, wherein "the earthly image of the Advent as a historical event is caught up and absorbed in the eternity of spiritual reality" $(1968,149)$. The nativity tableau thus clarifies and emphasizes the maternal body despite the metaphors that precede it.

The female body asserts itself again at the end of the poem. Like lactating breasts, the uterus is uniquely female. Advent uses the word hrif, womb, in its celebratory close. Like the unusual nativity tableau, hrif emphasizes the physiology of the female, creating tension with the previous metaphoric language and tropes:

ac pæt wæs ma cræft

ponne hit eorðbuend ealle cupa

purh geryne, hu he, rodera prim,

heofona heahfrea, helpe gefremede

monna cynne purh his modor hrif

(11.421b-425) 
[But that was greater craft than all the earth-dwelling ones could know through mystery, how he, the glory of the sky, of the high king of the heavens, created help for mankind through his mother's womb]

In these lines, the reference to hrif suddenly places the mother's body again in the foreground as it was at the nativity. The word hrif occurs 50 times in various forms (hrif, hrife, hrifes) throughout the Anglo-Saxon corpus (Healey and Venezky 1980). Most often, it occurs in medical texts to discuss uterine and other gynecological problems. ${ }^{12}$ It can mean belly more generally than womb. ${ }^{13}$ It is occasionally used to speak nonspecifically of people born from their mothers' wombs. ${ }^{14}$ Hrif refers specifically to Mary's womb eleven times, and she is the only specific woman whose womb is discussed in the entire Anglo-Saxon corpus. ${ }^{15}$ These eleven references come from religious texts produced within a practice and a theology that try not to acknowledge literal female physiology; ${ }^{16}$ the poem's use of the specifically bodily word hrif indicates the inevitable failure of that project.

Typology and poetry cannot quite eradicate the fact that Mary's maternity, epitomized in the nativity tableau and in the closing reference to her hrif, is based wholly in her body. Her epithet, "virgin," refers to her body, though once her intactness has been established, her virginity becomes a metaphor for purity rather than a physical description. The wholeness of the female body and the symbols that can be created from that wholeness tend to eclipse the actual body. One aspect of such wholeness, as manifested in Advent, is grammatical and metaphorical objectification of the female body that bore Christ and that still remained intact, sealed.

Advent attempts to construct Mary's femininity as that of an intact body which can be shrouded in metaphor, especially as a locked gate, and then made to disappear. Even so, Mary's own speech about her maternity empowers her to the point where she can issue commands to her husband; her lactating body forces the reader to focus on her in the nativity tableau; the use of hrif asserts the existence of the body even as the text celebrates Christ's divinity.

It is Mary's body that bears, nurtures, and protects the infant Christ. Within Christian texts, including Advent, it is through her body that Mary accrues maternal power. Such maternal power is based in nurturance rather than domination, love rather than fear; maternal power is no less strong because of its origins. Nurturance is a frequent topos in discussions of the Virgin, but it tends to be discussed only from the viewpoint of the recipient. The power implicit in Mary's maternal performance is the power of the nurturer; caring or nurturance is not taken by the child but given by the mother. The child is the one in need. No wonder Advent shies away from a focus on Mary as woman/mother, focusing instead on Christ while disembodying Mary through metaphor in the process. 
Although Mary is celebrated in Christian ideology for her nurturance and love, the focus is traditionally on the recipients of that nurturance and love (petitioners, the Christ child) rather than on the power Mary exercises as she provides them. A consistent focus on the (male) child in the mother-child relationship defines the mother as object, as Other, and attempts to neutralize the mother's maternal power. Advent performs this construction through metaphor and syntax, as I have shown above. To acknowledge that Mary acts with maternal power would be to undermine the supremacy of Christ. However, the figure of Mary does just that, expressing her authority in section seven even as she is simultaneously objectified by the grammar and metaphor of the section. Her body is at the forefront in the nativity tableau in lyric nine; it is explicit in the use of the word hrif at the poem's close. Through her body-not a metaphor, not an object-she reveals that the infant Christ is dependent upon her maternal power. She makes explicit Christian narrative's reliance on female physiology.

Such a focus on Mary's body can also enlarge our vision of Advent's historical context, providing insight into the history of women's spirituality. Scholars have tended to place the manuscript's reception firmly within a private, monastic context — a limited audience of educated males. Our perception of that audience can and should be expanded to include women, most likely nuns who would have engaged in the same sorts of private devotional reading that their monastic brothers did. My reading of Mary as active, embodied subject in the poem provides an entry for identifying just such a female audience.

This expansion of the poem's audience is valid in terms of both Conner and Clayton's suggested dates for the poem's composition. Clayton suggests dating the poem's composition to the early ninth century; acceptance of this early date entails as well our acceptance of the circulation of the poem, pre-Exeter Book, in contexts we cannot define (1990, 205-6). Just as the poem made its way into a collection for private reading in the monastery at Exeter, it may have earlier been included in private devotionals made by, made for, used by, or read to women. Michelle Brown's recent work with female book ownership in the early ninth century (2001) intersects with Clayton's dating of Advent's composition to suggest some fascinating possibilities, possibilities that can expand our understanding of the early audience of the poem from only male to both male and female.

Conner's date of the poem's composition is much closer to, if not identical with, the date of the manuscript's creation at about $1000 \mathrm{CE}$. This later date, the apex of the Benedictine reform, does not necessarily exclude women from the audience of Advent, even if it is construed as a poem received only within a monastic context. Professed religious women were never far from the foundation at Exeter. The Leofric Missal 
records a list of sureties, dated 968-993, between Abbess Eadgifu and Abbot Leofric for land at Stoke Canon in Devon; Eadgifu was almost certainly the abbess of a community supervised by Exeter Cathedral (Sawyer 1968). ${ }^{17}$ Knowles and Hadcock's Medieval Religious Houses suggests that Exeter itself may have been a double house for monks and nuns before the Benedictine reform; after c.968, "there was probably a separate nunnery" that complemented the monastery $(1971,473)$. Patricia Halpin (1994) and Barbara Yorke (1989) have both discussed the late Anglo-Saxon practice of high-status religious women holding estates that were geographically near to, and spiritually linked with, male monastic communities; such a structure may have been in effect in eleventh-century Exeter. In the 100 to 150 years that span the composition of the poem and the Exeter Book's creation (if we accept Clayton's date), and even after the book's creation (if we accept Conner's), women probably heard or read Advent at least occasionally during the Anglo-Saxon period. ${ }^{18}$ We need to include them in our critical analyses of the Exeter Book's audience, in its contemporary reception.

I'd like to close by suggesting that some of these women may have been drawn to Advent through some sense of personal identification with the embodied maternal performance of Mary. The unusual nativity tableau in particular could have been especially appealing to a woman who was also a mother-I know that in my first reading of the poem, it was the focal point of the lyrics for me, also a mother with an infant. Interestingly enough, many professed religious women of the Anglo-Saxon period were mothers. Stephanie Hollis (1992), Clare Lees and Gillian Overing (1998), and others have discussed in detail the unusual profile of the typical early Anglo-Saxon abbess-an aristocratic widow with children. Barbara Yorke has documented the early practice of widows retiring to religious communities to have continued into the tenth and eleventh centuries (1989), while Marc Meyer has discussed the power relationships between the Benedictine reform nunneries and late Anglo-Saxon queens, many of whom lived in those nunneries after their husbands' deaths (1977). The little we know about the other members of Anglo-Saxon female religious communities indicates that many of the choir nuns were widows and mothers as well. Although some aristocratic women in Anglo-Saxon England probably had wet nurses, most women nursed their own babies. In a time before baby formula and sterilized bottles, a lactating female body was the only available nourishment source for a newborn. A woman reading or listening to the Advent Lyrics one thousand years ago was more likely than not to have had pæt bearn foran breostum, to know the experience of the baby at her own breast and to identify with Mary at that point in the lyrics.

Mary's maternal performance in Advent-active, powerful, embodied, and celebrated-reveals an alternative devotional focus, different from 
the period's more usual Marian presentation of humility and metaphor. This performance suggests the possibility of a female as well as a male audience for the Exeter Book, bringing the manuscript out of its seclusion in the masculine space of the cathedral library and into the daily devotional lives of the women and men of late tenth-century Exeter. This reading of Advent also provides a specific historical context for the current women's studies interest in religious devotion, adding to our understanding of the history of women's relationships with Christianity.

I would like to thank for their assistance with this essay Nina RulonMiller, for an ongoing discussion about women's spirituality throughout history; Allen Frantzen, for continued professional support and inspiration; Michelle Brown, for generosity with pre-publication research; and the members of my writing group at the Lesley University Faculty Writing Retreat 2000: Donna Cole, Hollee Freeman, and Cheryl Smith.

Mary Dockray-Miller is Assistant Professor of English at Lesley College in Cambridge, MA. Her work focuses on Anglo-Saxon studies and women's history. She is the author of Motherhood and Mothering in Anglo-Saxon England (St. Martin's Press 2000). Send correspondence to Lesley College, 29 Everett St., Cambridge, MA 02138; mdockray@mail. lesley.edu.

\section{Notes}

1. The poem I refer to as Advent has a complicated editorial history because of its placement as the first poem in the Exeter Book. Manuscript evidence can be interpreted to show one long, three separate, or three related poems on Christ's advent, resurrection, and second coming. In 1900, A.S. Cook presented Christ as a long poem in three parts, all written by Cynewulf, in The Christ of Cynewulf. His lineation is continuous throughout his subtitled three sections ("Part I-The Advent," "Part II-The Ascension," "Part III-Doomsday"). G.P. Krapp and E. Dobbie, the editors of The Exeter Book, ASPR vol. 3 (1936), refer to Christ as a poem with "three distinct structural units" (xxvi) that they divide into Christ I (11.1-439), Christ II (11.440-866), and Christ III (11.8667-1664). More recently, Jackson Campbell (1959) and Robert Burlin (1968) have followed manuscript evidence that demarcates Advent (Christ I) as a separate poem and published editions that divide the poem into twelve sections, each corresponding to the antiphonal source for that section. While I will follow Cook's lineation for manuscript reasons (the manuscript does not divide the "twelve poems" as such but provides five fitt divisions at 11.71, 164, 275, and 378), I have found it convenient to refer to the individual "lyrics" or sections as they correspond to their antiphonal sources. Textual citations throughout are from Krapp and Dobbie. Translations are my own and are literal rather than poetic. 
2. For discussions of the antiphonal sources, see Cook (1900, xxxv-xliii); Campbell, Advent Lyrics (1959, 6-34); Dom Edward Burgart, The Dependence of Part I of Cynewulf's Christ upon the Antiphonary (1921); Thomas Hill, "A Liturgical Source for Christ I 164-213" (1977); Simon Tugwell, "Advent Lyrics 348-77 (Lyric no.10)" (1970).

3. Patrick W. Conner, Anglo-Saxon Exeter: A Tenth-Century Cultural History (1993), argues that the Exeter Book was made at Exeter; Richard Gameson disagrees (and suggests Canterbury) in "The Origin of the Exeter Book of Old English Poetry" (1996). Conner includes detailed description and discussion of the manuscript, which is traditionally dated to c.1000. Bernard Muir's The Exeter Anthology of Old English Poetry (1994) provides the most recent complete edition of the manuscript, although he differs substantially from Conner in his theories about the manuscript's compilation.

4. For example, Conner assumes a male audience for the entire book, referring repeatedly to "the monk" as reader as he delineates the poem's "celebrations of the images and symbols which make monasticism possible" (1993, $162)$.

5. For similarly focused treatments, see Stanley Greenfield and Daniel Calder, A New Critical History of Old English Literature (1986, 187-8); Barbara Raw, "Biblical Literature: The New Testament" $(1991,233)$; Ward Parks, "Mystery and the Word: The Search for Knowledge in the Old English Advent Lyrics" (1982); Earl Anderson, "Mary's Role as Eiron in Christ I" (1971).

6. Text and translation, lines 301-25:

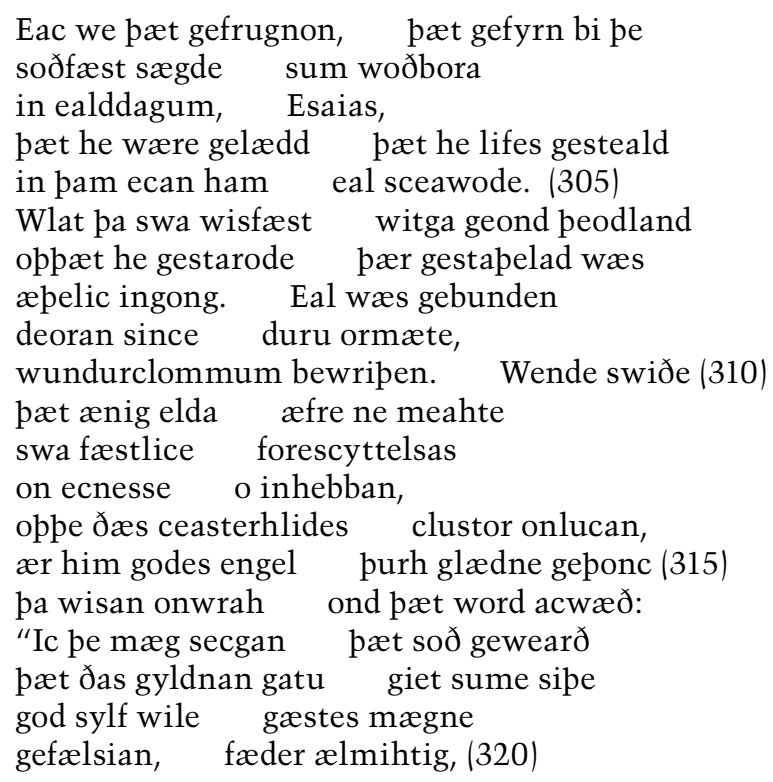




$$
\begin{aligned}
& \text { ond purh pa fæsten locu foldan neosan, } \\
& \text { ond hio ponne æfter him ece stondað } \\
& \text { simle singales swa beclysed } \\
& \text { pæt nænig oper, nymðe nergend god, } \\
& \text { hy æfre ma eft onluceð." (325) }
\end{aligned}
$$

[Also we have heard that which one truth-fast wiseman, Isaiah, said about you formerly in older days, that he was guided so that he gazed at all life's dwelling in the eternal home. The wisdom-fast prophet then looked thus beyond this empire so that he stared where a noble gate was standing. The door was all adorned with boundless precious treasure, wound with wondrous bands. He thought fiercely that no man might ever raise thus those bolts firm in eternity, or unlock that city-gate's barrier, until to him, the wise man, God's angel through glad thoughts explained and spoke these words: "I may tell you what truly happened-that God himself, the Almighty Father, will pass through this golden gate still at some time with the spirit's power, and through the fastened locks will visit the earth, and the gates then after him stand eternally, forever, always thus closed, so that none other, except the savior God, might ever them again unlock."]

7. For a recent discussion of the metaphor of the locked gates as a figure for both Mary and the Anglo-Saxon Queen Edith, see Monika Otter, "Closed Doors: An Epithalamium for Queen Edith, Widow and Virgin" (1999). See as well Lara Farina, "Before Affection: Christ I and the Social Erotic" (2001), which unfortunately appeared too late for me to engage with its provocative analysis.

8. See Craig Williamson, The Old English Riddles of the Exeter Book (1977). The key/penis riddle is number 42 in Williamson's numeration.

9. For a discussion of the Marian apocrypha in Anglo-Saxon England, see Clayton, The Cult of the Virgin Mary in Anglo-Saxon England (1990).

10. Since the manuscript does not provide speech designations, speech assignment has formed the focus of critical debate about the seventh section of Advent. For a recent discussion, see Clayton, The Cult of the Virgin Mary $(1990,191-7)$. Other treatments of speech assignments in these lines include Earl Anderson, "The Speech Boundaries in Advent Lyric VII" (1979); John Foley, "Christ 164-213: A Structural Approach to the Speech Boundaries in Advent Lyric Seven" (1975); Judith Garde, "Christ I (164-195a): The MaryJoseph Dialogue in Medieval Christian Perspective" (1990); C.G. Harlow, "The Old English Advent VII and the Doubting of Mary Tradition" (1985); Thomas Hill, "A Liturgical Source for Christ I 164-213" (1977); Neil Isaacs, "Who Says What in Advent Lyric VII?" (1966); Cook (1900, 96-8), Campbell $(1959,22-5)$, and Burlin $(1968,116-25)$ also provide overviews.

11. In a contrast to my argument, Ann Klinck argues that Mary represents a strong, active, female point of view that focuses on relationships and feelings, 
convincing Joseph of the moral rectitude of her pregnancy because she enacts "the role of the submissive, but psychologically dominant, wife" $(1979,598)$.

12. There are seventeen medical uses of hrif, most from Bald's Leechbook (Healey and Venezky 1980).

13. For example, the Laws of Alfred include specific fines gif mon bid on hrif wund (if a person is wounded in the belly) (Healey and Venezky 1980).

14. The Old English text of the Gospel of Matthew, for instance, generally discusses eunuchs who are formed so in their mothers' wombs without referring to a specific person (Healey and Venezky 1980).

15. Mary's womb is specifically mentioned not just in Advent but in The Fates of the Apostles, Blickling Homilies \#1 and \#3, the Gospel of Matthew, the Gospel of Luke, the Durham Ritual Liturgical Texts, and a confessional prayer (Healey and Venezky 1980).

16. For a discussion of the body and sexuality in Anglo-Saxon literature, see Hugh Magennis, "'No Sex Please, We're Anglo-Saxon'?" (1995).

17. P.H. Sawyer's work is available online in searchable format at http://www. trin.cam.ac.uk/chartwww/; the charter in question is his \#1452, also available in Walter de Grey Birch as charter \#1244 (1885).

18. A similarly female reception is suggested for Juliana, another of the Exeter Book's poems, by Shari Horner (1994).

\section{References}

Anderson, Earl. 1979. "The Speech Boundaries in Advent Lyric VII." Neophilologus 63: 611-18.

- 1971. "Mary's Role as Eiron in Christ I." Journal of English and Germanic Philology 70:230-40.

Birch, Walter de Grey, ed. 1885. Carularium Saxonicum, 3 vols. London: Whiting and Company.

Brown, Michelle. 2001. "Female Book Ownership and Production in England During the Ninth Century: The Evidence of the Prayerbooks." In Lexis and Texts in Early English: Essays Presented to Jane Roberts, eds Christian J. Kay and Lousie M. Sylvester, 45-67. Amsterdam: Rodopi.

Burgart, Dom Edward. 1921. The Dependence of Part I of Cynewulf's Christ upon the Antiphonary. Washington, DC: Catholic University Press.

Burlin, Robert, ed. 1968. The Old English Advent. New Haven, CT: Yale University Press.

Campbell, Jackson, ed. 1959. The Advent Lyrics of the Exeter Book. Princeton, NJ: Princeton University Press. 
Chance, Jane. 1986. Woman as Hero in Old English Literature. Syracuse, NY: Syracuse University Press.

Clayton, Mary. 1990. The Cult of the Virgin Mary in Anglo-Saxon England. Cambridge, UK: Cambridge University Press.

Conner, Patrick W. 1993. Anglo-Saxon Exeter: A Tenth-Century Cultural History. Woodbridge, UK: Boydell.

Cook, Albert Stanburrough., ed. 1900. The Christ of Cynewulf. Boston: Athenæum Press.

Farina, Lara. 2001. "Before Affection: Christ I and the Social Erotic." Exemplaria 13:469-96.

Foley, John M. 1975. "Christ 164-213: A Structural Approach to the Speech Boundaries in Advent Lyric Seven." Neophilologus 59:114-18.

Gameson, Richard. 1996. "The Origin of the Exeter Book of Old English Poetry." Anglo-Saxon England 25:135-85.

Garde, Judith. 1990. "Christ I (164-195a): The Mary-Joseph Dialogue in Medieval Christian Perspective." Neophilologus 74:122-30.

Greenfield, Stanley, and Daniel Calder. 1986. A New Critical History of Old English Literature. New York: New York University Press.

Halpin, Patricia. 1994. "Women Religious in Late Anglo-Saxon England." Haskins Society Journal 6:97-110.

Harlow, C.G. 1985. "The Old English Advent VII and the Doubting of Mary Tradition." Leeds Studies in English 16:101-17.

Healey, Antonette di Paolo, and Richard Venezky, eds. 1980. A Microfiche Concordance to Old English. Newark, NJ: University of Delaware Microfilms.

Hill, Thomas. 1977. "A Liturgical Source for Christ I 164-213." Medium Ævum 46:12-15.

Hollis, Stephanie. 1992. Anglo-Saxon Women and the Church. Woodbridge, UK: Boydell and Brewer.

Horner Shari. 1994. "Spiritual Truth and Sexual Violence: The Old English Juliana, Anglo-Saxon Nuns, and the Discourse of Female Monastic Enclosure." Signs 19:658-76.

Irving, Edward. 1996. "The Advent of Poetry: Christ I" Anglo-Saxon England 25:123-34.

Isaacs, Neil. 1966. "Who Says What in Advent Lyric VII?" Papers on Language and Literature 2:162-6.

Klinck, Ann. 1979. "Female Characterization in Old English Poetry and the Growth of Psychological Realism: Genesis B and Christ I." Neophilologus 63:597-610.

Knowles, David, and R. Neville Hadcock. 1971. Medieval Religious Houses: England and Wales. $2^{\text {nd }}$ ed. London: Longman.

Krapp, George Philip, and Elliot van Kirk Dobbie, eds. 1936. The Exeter Book, ASPR Vol. 3. New York: Columbia University Press.

Lees, Clare. 1997. “Engendering Religious Desire: Sex, Knowledge, and Christian Identity in Anglo-Saxon England." Journal of Medieval and Early Modern Studies 27:17-45.

Lees, Clare, and Gillian Overing. 1998. "Before History, Before Difference: Bodies, Metaphor, and the Church in Anglo-Saxon England." Yale Journal of Criticism 11(2):315-34. 
Magennis, Hugh. 1995. "'No Sex Please, We're Anglo-Saxon'? Attitudes to Sexuality in Old English Prose and Poetry." Leeds Studies in English 26:1-27.

Meyer, Marc A. 1977. "Women and the Tenth Century English Monastic Reform." Revue Benedictine 87:34-61.

Muir, Bernard. 1994. The Exeter Anthology of Old English Poetry. Exeter, UK: University of Exeter Press.

Otter, Monika. 1999. "Closed Doors: An Epithalamium for Queen Edith, Widow and Virgin." In Constructions of Widowhood and Virginity in the Middle Ages, eds. Cindy L. Carlson and Angela Jane Weisl, 63-94. New York: St. Martin's Press.

Parks, Ward. 1982. "Mystery and the Word: The Search for Knowledge in the Old English Advent Lyrics." Ball State University Forum 23:71-9.

Raw, Barbara. 1991. "Biblical Literature: The New Testament." In The Cambridge Companion to Old English Literature, eds. Malcolm Godden and Michael Lapidge, 227-42. Cambridge, UK: Cambridge University Press.

Sawyer, P.H., ed. 1968. Anglo-Saxon Charters: An Annotated List and Bibliography. London: Royal Historical Society.

Tugwell, Simon. 1970. "Advent Lyrics 348-77 (Lyric no.10)." Medium AEvum 39:34.

Williamson, Craig, ed. 1977. The Old English Riddles of the Exeter Book. Chapel Hill: University of North Carolina Press.

Yorke, Barbara. 1989. "Sisters Under the Skin? Anglo-Saxon Nuns and Nunneries in Southern England." Reading Medieval Studies 15:95-117. 
Copyright $\odot 2002$ EBSCO Publishing 
Copyright of NWSA Journal is the property of Johns Hopkins University Press and its content may not be copied or emailed to multiple sites or posted to a listserv without the copyright holder's express written permission. However, users may print, download, or email articles for individual use. 